\title{
Perhitungan Premi Netto Tahunan Dalam Menganalisis Komponen Biaya Pada Perusahaan Asuransi Jiwa Bumiputera
}

\author{
Sumiati Tamalonggehe ${ }^{1}$, Altien J. Rindengan ${ }^{2}$, Tohap Manurung $3^{3 *}$ \\ 1,2,3 Program Studi Matematika, Fakultas Matematika dan Ilmu Pengetahuan Alam, \\ Universitas Sam Ratulangi Manado \\ *corresponding author email : $\underline{\text { Kris_ton79@yahoo.com }}$
}

\begin{abstract}
Abstrak
Sekarang ini banyak jenis asuransi di Indonesia, salah satu jenis asuransi yaitu asuransi jiwa. Disadari bahwa asuransi mempunyai beberapa manfaat antara lain, membantu masyarakat dalam rangka mengatasi segala masalah risiko yang dihadapinya. Penelitian ini bertujuan untuk mengetahui besaran masing-masing komponen dan menghitung serta menganalisis bagaimana menentukan perhitungan premi netto pada asuransi jiwa dwiguna dengan menggunakan metode invers matriks. Sumber data diambil dari Asuransi Jiwa Bumi Putera. Dari hasil penelitian dapat disimpulkan bahwa untuk masa pertanggungan 4 tahun besaran komponenkomponen biaya untuk uang pertanggungan sebesar Rp. 1.500,000 dengan demikian untuk biaya penutupan baru sebesar Rp. 11.199,1821 dan Rp. 0,0299, biaya pengumpulan premi sebesar Rp. 0,9030 dan biaya untuk pemeliharaan sebesar Rp. 10,832.6678. dengan premi neto tahunan untuk usia 17 tahun adalah Rp. 279.162, untuk usia 18 tahun sebesar Rp. 279.279, untuk usia 19 tahu sebesar Rp. 279.336, untuk usia 20 tahun sebesar Rp. 279.355 .
\end{abstract}

Kata kunci: Asuransi Jiwa Dwiguna, Invers Matriks, Analisis Biaya

\section{Annual Net Premium Estimation In Analyse Of Cost Components on Bumiputra Life Insurance Company}

\begin{abstract}
Currently there are many types of insurances in Indonesia, one of those is life insurance. In the knowledge that insurance has benefits and one of them is to help the community to overcome all the risk issues, this research aims to determine the value of components, calculate and analyse how to determine the net premium on endowment life insurance by using inverse matrix method. The data source is taken from Bumi Putera Life Insurance Company. The result indicates that for period of 4 years the components value of sum assured is Rp. 1.500.000, closing fee is Rp. 11.199,1821 and Rp. 0,0299, collecting premium cost is Rp. 0,9030 and maintenance cost Rp. 10.832,6678. Annual net premium for the age of 17 is Rp. 279.162, for the age of 18 is Rp. 279.162, for the age of 19 is Rp. 279.336 and for the age of 20 is Rp. 279.355.
\end{abstract}

Keywords: Life Insurance Company, Inverse Matrix, Cost Analysis

\section{Pendahuluan}

Sekarang ini banyak jenis asuransi di Indonesia, salah satu jenis asuransi yaitu asuransi jiwa. Disadari bahwa asuransi mempunyai beberapa manfaat antara lain pertama, membantu masyarakat dalam rangka mengatasi segala masalah risiko yang dihadapinya. Hal itu akan memberikan ketenangan dan kepercayaan diri yang lebih tinggi kepada yang bersangkutan. Kedua, asuransi merupakan sarana pengumpulan dana yang cukup besar sehingga dapat dimanfaatkan untuk kepentingan masyarakat dana pembangunan. Ketiga, sebagai sarana untuk mengatasi risiko - risiko yang dihadapi dalam melaksanakan pembangunan. Selain itu, meskipun banyak metode untuk menangani risiko, asuransi merupakan metode yang paling banyak dipakai. Karena asuransi menjanjikan perlindungan kepada pihak tertanggung terhadap risiko yang dihadapi perorangan maupun risiko yang dihadapi oleh perusahaan [1]. 
Pada asuransi jiwa yang dipertanggungkan ialah yang disebabkan oleh kematian. Kematian tersebut mengakibatkan hilangnya pendapatan seseorang atau suatu keluarga tertentu. Pergantian untuk suatu risiko yang mungkin akan diderita karena suatu peristiwa tertentu, diperoleh dari pembayaran sebuah premi. Pada perhitungan premi asuransi, ada beberapa hal yang diperhatikan yaitu faktor mortalitas, faktor bunga, dan faktor biaya [2]

- Factor Mmrtalitas

- Factor bunga

- Factor biaya

Biaya yang tercantum dalam suatu pembayaran premi memiliki beberapa komponen yakni :

1. Biaya penutupan baru $\left(\alpha_{1} \alpha_{2}\right)$

$\left(\alpha_{1}\right)$ : Biaya yang dilakukan pada awal tahun

$\left(\alpha_{2}\right)$ : Biaya yang dilakukan di akhir tahun

2. Biaya pengumpulan premi $(\beta)$

3. Biaya pemeliharaan, $(\gamma)$

Perhitungan Premi yang hanya didasarkan atas tingkat bunga dan tabel mortalitas saja disebut Netto Premium. Sedangkan premi yang telah ditambahkan biaya adalah premi yang harus dibayarkan oleh peserta asuransi yang disebut premi bruto (gross premium) [3].

Perjanjian asuransi jiwa pembayaran premi biasanya dapat dilakukan secara sekaligus atau dibayar secara tunai, tetapi dapat juga secara periodik yaitu tahunan, setengah tahun, triwulan, dan bulanan. Premi harus dibayar tepat waktu dan jumlahnya biasanya ditentukan oleh pihak penanggung. Apabila dalam perjanjian asuransi pihak tertanggung tidak dapat melaksanakan kewajibannya membayar premi lanjutannya tepat waktu atau pembayaran preminya terhenti sebelum masa pertanggungannya berakhir, maka pihak penanggung dapat membatalkan perjanjian asuransi.

Premi netto dan biaya merupakan dua faktor yang mempengaruhi perhitungan premi bruto, sehingga pada penelitian ini dilakukan analisis untuk mengetahui besarnya premi netto dan digunakan metode invers matriks untuk memperoleh nilai dari masing-masing komponen biaya.

\section{Asuransi}

Asuransi atau pertanggungan adalah perjanjian antara dua pihak atau lebih, dengan mana pihak penanggung mengikatkan diri kepada tertanggung, dengan menerima premi asuransi, untuk memberikan penggantian kepada tertanggung, karena kerugian, kerusakan atau kehilangan keuntungan yang diharapkan, atau tanggung jawab hukum kepada pihak ketiga yang mungkin diderita tertanggung, yang timbul dari suatu peristiwa yang tidak pasti, atau untuk memberikan suatu pembayaran yang didasarkan atas meninggalnya atau hidupnya seseorang yang dipertanggungkan[4].

Ada beberapa jenis asuransi jiwa yang ada, namun yang saya ambil adalah asuransi jiwa dwiguna. Berikut adalah jenis-jenis asuransi yaitu :

- Asuransi Berjangka

- $\quad$ Asuransi Seumur hidup

- Asuransi Dwiguna

- $\quad$ Asuransi Unit Link

Asuransi jiwa merupakan perjanjian atau kesepakatan dari sejumlah orang untuk memikul kesulitan dan risiko keuangan bila terjadi musibah pada salah satu anggotanya. Setiap orang yang mengasuransikan jiwanya pada suatu perusahaan asuransi berarti telah sepakat pada perjanjian tertulis antara dirinya dengan perusahaan asuransi. Asuransi Jiwa dwiguna (endowment) yaitu asuransi jiwa yang hampir sama dengan asuransi jiwa berjangka. Bedanya, Asuransi Jiwa Dwiguna menjamin pemberian uang tunai yang besarnya bisa sejumlah uang pertanggungan atau sejumlah pengembalian premi yang sudah dibayar berikut hasil investasinya [5].

\subsection{Tabel Mortalita}

Tabel mortalita adalah salah satu elemen penting dalam mengkalkulasi premi, yang berguna untuk mengetahui besarnya klaim yang disebabkan kematian, dan meramalkan berapa lama batas waktu (usia) rata-rata seseorang bisa hidup [6].

Sebagai contoh untuk memberikan gambaran tentang tabel mortalita disajikan pada tabel 1 [7] : 
Tabel 1. Bentuk Rumus Mortalita

\begin{tabular}{|c|c|}
\hline Rumus & Keterangan \\
\hline$l_{x}$ & Menyatakan jumlah orang yang berumur $x$ \\
\hline$d_{x}=l_{x}-l_{x+1}$ & $\begin{array}{l}\text { Menyatakan jumlah orang yang berumur } x \text { yang akan } \\
\text { meninggal sebelum mencapai umur } x+1\end{array}$ \\
\hline${ }_{n} P_{x}=\frac{l_{x+n}}{l_{x}}=1-{ }_{n} q_{x}$ & $\begin{array}{l}\text { Menyatakan peluang orang yang berumur } x \text { akan hidup } \\
\text { mencapai umur } x+n\end{array}$ \\
\hline${ }_{\mathrm{n}} q_{x}=\frac{l_{x}-l_{x+n}}{l_{x}}=1-{ }_{\mathrm{n}} P_{x}$ & $\begin{array}{l}\text { Menyatakan peluang orang yang berumur } x \text { akan meninggal } \\
\text { sebelum mencapai umur } x+n\end{array}$ \\
\hline $\mathrm{n} / \mathrm{n} q_{x}=\frac{l_{x+m}-l_{x+n+m}}{l_{x}}$ & $\begin{array}{l}\text { Menyatakan peluang orang yang berumur } \mathrm{x} \text { akan hidup } \\
\text { mencapai umur } x+n \text { tetapi akan meninggal sebelum umur } \\
x+n+m\end{array}$ \\
\hline $\begin{array}{l}e_{x}=\frac{1}{l_{x}}\left(l_{x+1}+l_{x+2}+\cdots+l_{w}\right) \\
={ }_{1} P_{x}+{ }_{2} P_{x}+{ }_{3} P_{x}+\cdots+{ }_{w} P_{x}\end{array}$ & Lama hidup yang dapat dicapai (harapan hidup) \\
\hline
\end{tabular}

\subsection{Anuitas Hidup}

Terdapat 2 macam anuitas yaitu anuitas hidup dan anuitas tunggal/ tentu. Sedangkan yang digunakan dalam perhitungan atau menganlisis premi ialah anuitas hidup.

Anuitas hidup adalah serangkaian pembayaran yang dilakukan secara terus-menerus pada interval yang sama ( bulan,tahun) selama tertanggung masih hidup. Pembayaran dapat dilakukan beberapa waktu saja atau selama tertanggung hidup. beberapa jenis asuransi jiwa, memberikan bentuk lain dari manfaat pendapatan. sehingga, misalnya, penghasilan bulanan dibayarkan untuk asuransi pasangan hidup, atau untuk pensiun yang diasuransikan [8].

Untuk menyederhanakan perhitungan annuitas hidup dan perhitungan lainnya, maka digunakan suatu simbol komutasi yaitu [3].:

dengan :

$$
D_{x}=v^{x} l_{x}
$$

$D_{x}=$ orang yang masih hidup dalam umur $\mathrm{x}$

$v=\frac{1}{1+i} \quad(\mathrm{i}=$ diskon $)$

$l_{x}=$ Jumlah yang hidup

$$
\begin{aligned}
N_{x} & =D_{x}+D_{x+1}+\cdots+D_{\omega} \\
C_{x} & =v^{x+1} d_{x} \\
M_{x} & =C_{x}+C_{x+1}+\cdots+C_{\omega}
\end{aligned}
$$

dengan :

$N_{x}=$ jumlah seluruh orang yang hidup dalam umur $\mathrm{x}$

$C_{x}=$ orang yang meninggal dalam umur $\mathrm{x}$

$M_{x}=$ jumlah seluruh orang yang meninggal dalam umur $\mathrm{x}$

Anuitas hidup berjangka akhir

dengan :

$$
a_{x: \bar{n} \mid}={ }_{v} P_{x}+v^{2}{ }_{2} P_{x}+\cdots+v^{n}{ }_{\mathrm{n}} P_{x}=\frac{N_{x+1}-N_{x+n+1}}{D_{x}}
$$

$a_{x: \bar{n} \mid}=$ Anuitas sementara akhir tahun

${ }_{\mathrm{n}} P_{x}=$ Peluang orang hidup sampai umur $\mathrm{x}+\mathrm{n}$ 
$N_{x}=$ Jumlah seluruh orang yang hidup dalam umur $\mathrm{x}$

$D_{x}=$ Orang yang masih hidup dalam umur $\mathrm{x}$

$v$ = umur sekarang

Anuitas hidup berjangka awal

$$
\left(\ddot{a}_{x: \bar{n} \mid}\right)=1+{ }_{\mathrm{v}} P_{x}+\cdots+v^{n-1}{ }_{\mathrm{n}-1} P_{x}=\frac{N_{x}-N_{x+n}}{D_{x}}
$$

dengan :

$\ddot{a}_{x: \bar{n} \mid}=$ Anuitas sementara awal tahun

${ }_{\mathrm{n}} P_{x}=$ Peluang orang hidup sampai umur $\mathrm{x}+\mathrm{n}$

$v$ = umur sekarang

$N_{x}=$ jumlah seluruh orang yang hidup dalam umur $\mathrm{x}$

$D_{x}=$ orang yang masih hidup dalam umur $\mathrm{x}$

\subsection{Premi}

Premi merupakan sejumlah uang yang dibayarkan oleh tertanggung kepada penanggung sebagai bayaran untuk pergantian risiko atau klaim yang terjadi.

Premi Bersih (Net Premi)

Premi bersih ( Net Premi ) adalah pembayaran premi asuransi yang dilakukan 1 kali pada waktu kontrak asuransi disetujui, selanjutnya tidak ada pembayaran lagi. Premi tunggal bersih asuransi jiwa dwiguna dilambangkan dengan $A_{x: \bar{n} \mid}$ dengan perhitungan [7].

$$
A_{x: \bar{n} \mid}=\frac{M_{x}-M_{x+n}+D_{x+n}}{D_{x}}
$$

Untuk pembayaran premi tahunan asuransi jiwa dwiguna dilambangkan dengan $P_{x: \bar{n} \mid}$ perhitungan perbandingan antara premi tunggal bersih asuransi jiwa dwiguna dengan anuitas hidup berjangka dari seseorang peserta asuransi.

Premi kotor (Gross Premi)

$$
P_{x: \overline{1} \mid}=\frac{M_{x}-M_{x+n}+D_{x+n}}{N_{x}-N_{x+n}}
$$

Jumlah premi yang diterima dari pemegang polis disebut Gross Premi. Gross premi ini jumlahnya lebih besar dari net premi, selisih antara gross premi dan net premi disebut Loading (Biaya). Loading yang diterima oleh perusahaan asuransi jiwa digunakan untuk biaya pemeliharaan administrasi pemegang polis, juga merupakan sumber pendapat bunga yang digunakan untuk keperluan cadangan [7].

Untuk gross premi dinotasikan dengan $P^{*}$ atau $A^{*}$ dan untuk gross premi tahunan menggunakan notasi $P^{*}$ dengan rumus sebagai berikut:

Atau

$$
P^{*}=P(1+k)
$$

$$
P^{*}=P(1+k)+C
$$

Komponen biaya dalam pembayaran premi

Terdapat macam-macam biaya yang mungkin muncul dalam perhitungan premi kotor antara lain:

- Biaya penutupan baru $\left(\alpha_{1}, \alpha_{2}\right)$

Biaya penutupan baru terdiri dari : biaya biaya komisi supervisor asuransi, biaya dinas luar, biaya pembuatan polis, biaya iklan/ reklame, dan sales promotion.

Untuk $\alpha_{1}$ : Biaya yang dilakukan pada awal tahun

Untuk $\alpha_{2}$ : Biaya yang dilakukan pada saat akhir tahun

- Biaya pengumpulan premi $(\beta)$

Biaya pengumpulan premi ada sepanjang jangka pertanggungan premi, besar uang pertanggungan 1 dinotasikan dengan $\beta$

- Biaya pemeliharaan

Biaya pemeliharaan terdiri dari : Biaya listrik, air, gedung, dan sebagainya, Berlaku tiap awal tahun polis selama masa pertanggungan $(\gamma)[3]$ 


$$
P_{x: \overline{n \mid}}^{\overrightarrow{ }}=\frac{A_{x: \bar{n} \mid}+\alpha_{1}+\gamma \ddot{a}_{x: \bar{n} \mid}}{\left((1-\beta) a_{x: \bar{n} \mid}\right)-\alpha_{2} n}
$$

\section{Sistem Persamaan Linier}

Secara umum kita mendefinisikan persamaan linier dengan $\mathrm{n}$ variabel yaitu $x_{1}, x_{2}, \ldots, x_{n}$ sebagai suatu persamaanyang dapat dituliskan dalam bentuk

$$
a_{1} x_{1}+a_{2} x_{2} \ldots+a_{n} x_{n}=b
$$

dimana $a_{1}, a_{2}, \ldots, a_{n}$ dan $b$ adalah konstanta.

Pencarian solusi dari sistem persamaan linear ini menggunakan penerapan matriks, pada sistem aljabar linear ada banyak cara yang dapat digunakan untuk mencari solusi sistem persamaan linear salah satunya adalah dengan menggunakan metode Invers Matriks [9]

Jika $A$ adalah matriks ukuran $n \times n$ dan jika ada matriks $B$ ukuran $n x n$ sedemikian rupa sehingga $A B=B A=I$, dimana I adalah matriks identitas ukuran $n x n$, maka matriks $A$ disebut non singular atau invertible dan matriks $A$ merupakan invers dari $B$ atau $B$ merupakan invers dari $A$. Jika matriks $A$ tidak mempunyai invers, maka A disebut matriks singular atau non invertible [10]

$$
\begin{aligned}
& a_{11} x_{1}+a_{12} y_{2} \ldots a_{1 n} z_{n}=b_{1} \\
& a_{21} x_{1}+a_{22} y_{2} \ldots \quad a_{23} z_{n}=b_{2} \\
& a_{m 1} x_{1}+a_{m 2} y_{2} \ldots a_{m n} z_{n}=b_{m}
\end{aligned}
$$

Dapat dituliskan ke dalam bentuk matriks sebagai berikut

$$
\begin{gathered}
{\left[\begin{array}{cccc}
a_{11} & a_{12} & \cdots & a_{1 n} \\
a_{21} & a_{22} & \cdots & a_{2 n} \\
\vdots & \vdots & & \vdots \\
a_{m 1} & a_{m 2} & \cdots & a_{m n}
\end{array}\right]\left[\begin{array}{l}
x_{1} \\
y_{1} \\
\vdots \\
z_{1}
\end{array}\right]=\left[\begin{array}{l}
b_{1} \\
b_{2} \\
\vdots \\
b_{m}
\end{array}\right]} \\
{\left[\begin{array}{l}
x_{1} \\
y_{1} \\
\vdots \\
z_{1}
\end{array}\right]=\left[\begin{array}{cccc}
a_{11} & a_{12} & \cdots & a_{1 n} \\
a_{21} & a_{22} & \cdots & a_{2 n} \\
\vdots & \vdots & & \vdots \\
a_{m 1} & a_{m 2} & \cdots & a_{m n}
\end{array}\right]^{-1}\left[\begin{array}{l}
b_{1} \\
b_{2} \\
\vdots \\
b_{m}
\end{array}\right]}
\end{gathered}
$$

\section{Metodologi Penelitian}

Penelitian ini telah dilakukan selama 5 bulan. Dimulai dari bulan Februari 2017 hingga Juli 2017. Analisis data telah di laksanakan di laboratorium konsultasi statistika Matematika, Fakultas Matematika dan Ilmu Pengetahuan Alam, Universitas Sam Ratulangi, Manado.

Data yang digunakan pada penelitian ini ialah data sekunder yang diperoleh dari Perusahaan Asuransi Jiwa Dwiguna. Selain menggunakan data dari perusahaan Asuransi Jiwa Bumiputera, digunakan pula data dari tabel mortalita. Tahapan-tahapan yang dilakukan dalam proses analisis data pada penelitian ini yaitu :
a. Pengumpulan Data
b. Menghitung Premi Netto
c. Membentuk Persamaan
d. Analisis Komponen-komponen biaya
e. Kesimpulan

\section{Hasil dan Pembahasan}

Hasil perhitungan dari $D_{x}, N_{x}, \bar{C}_{x}, M_{x}$ dengan menggunakan tabel mortalita disajikan pada tabel 2.

Tabel 2. Perhitungan $D_{x}, N_{x}, \bar{C}_{x}, M_{x}$

\begin{tabular}{|r|r|r|r|r|}
\hline $\mathrm{X}$ & $D_{x}$ & $N_{x}$ & $\bar{C}_{\boldsymbol{x}}$ & $M_{\boldsymbol{x}}$ \\
\hline 0 & 100000,0000 & 870795,8314 & 3040,6103 & 4461,8641 \\
\hline 1 & 86131,1300 & 770795,8314 & 295,7749 & 1421,2537 \\
\hline 2 & 76377,7100 & 684664,6994 & 188,7853 & 1125,4788 \\
\hline
\end{tabular}




\begin{tabular}{|c|c|c|c|c|}
\hline $\mathrm{X}$ & $D_{x}$ & $N_{x}$ & $\bar{C}_{x}$ & $M_{x}$ \\
\hline 3 & 67797,5800 & 608286,9849 & 128,5570 & 936,6935 \\
\hline 4 & 60218,1300 & 540489,4070 & 96,5760 & 808,1365 \\
\hline 5 & 53502,9400 & 480271,2784 & 79,7510 & 711,5601 \\
\hline 6 & 47542,5400 & 426768,3404 & 69,0675 & 631,8090 \\
\hline 7 & 42247,0900 & 379225,8016 & 57,3923 & 562,7415 \\
\hline 8 & 37545,6100 & 336978,7135 & 46,4007 & 505,3492 \\
\hline 9 & 33371,8300 & 299433,1024 & 35,8906 & 458,9485 \\
\hline 10 & 29666,9600 & 266061,2751 & 28,8270 & 423,0579 \\
\hline 11 & 26376,2500 & 236394,3190 & 24,1366 & 394,2309 \\
\hline 12 & 23451,9800 & 210018,0676 & 21,2397 & 370,0943 \\
\hline 13 & 20852,0800 & 186566,0833 & 19,2784 & 348,8545 \\
\hline 14 & 18540,3700 & 165713,9990 & 18,5403 & 329,5762 \\
\hline 15 & 16483,2200 & 147173,6272 & 19,2822 & 311,0359 \\
\hline 16 & 14651,9100 & 130690,4055 & 20,5953 & 291,7537 \\
\hline 17 & 13020,7800 & 116038,4971 & 21,8650 & 271,1584 \\
\hline 18 & 11567,6500 & 103017,7179 & 21,9350 & 249,2934 \\
\hline 19 & 10274,3300 & 91450,0666 & 20,7429 & 227,3584 \\
\hline 20 & 9124,6540 & 81175,7392 & 18,7659 & 206,6155 \\
\hline 21 & 8103,0990 & 72051,0856 & 16,8180 & 187,8496 \\
\hline 22 & 7195,9850 & 63947,9867 & 15,0709 & 171,0317 \\
\hline 23 & 6390,2090 & 56752,0021 & 13,4435 & 155,9608 \\
\hline 24 & 5674,5790 & 50361,7927 & 12,2592 & 142,5172 \\
\hline 25 & 5038,8280 & 44687,2136 & 10,7906 & 130,2581 \\
\hline
\end{tabular}

dimana $D_{x}=$ banyaknya orang yang hidup dalam umur $x$

$N_{x}=$ jumlah seluruh orang yang hidup dalam umur $x$

$\bar{C}_{x}=$ banyaknya orang yang meninggal dalam umur $x$

$M_{x}=$ jumlah seluruh orang yang meninggal dalam umur $x$

\subsection{Perhitungan Premi Neto}

Untuk uang pertanggungan sebesar Rp. 1.500.000 dengan usiau 17, 18, 19, dan 20 tahun dilakukan perhitungan dengan menggunakan persamaan (10) sebagai berikut :

- Untuk usia 17 tahun

Jika tertanggung meninggal dalam masa asuransi, maka kepada tertanggung akan dibayarkan sebesar uang pertanggungan. Begitu sebaliknya, yaitu dengan perhitungan dibawah.

$P_{17: \overline{4} \mid}=1.500 .000 \frac{\left(M_{17}-M_{17+4}+D_{17+4}\right)}{N_{17}-N_{17+4}}$ 


$$
\begin{aligned}
& =1.500 .000 \frac{271,1584-187,8496+8103,099}{116038,4971-72051,0856} \\
& =R p 279.162
\end{aligned}
$$

- $\quad$ Untuk usia 18 tahun

Jika tertanggung meninggal dalam masa asuransi, maka kepada tertanggung akan dibayarkan sebesar uang pertanggungan. Begitu sebaliknya, yaitu dengan perhitungan dibawah ini.

$$
\begin{aligned}
P_{18: \overline{4} \mid} & =1.500 .000 \frac{\left(M_{18}-M_{18+4}+D_{18+4}\right)}{N_{18}-N_{18+4}} \\
& =1.500 .000 \frac{249,2934-171,0317+7195,985}{103017,7179} \\
& =R p 279.279
\end{aligned}
$$

- $\quad$ Untuk usia 19 tahun

Jika tertanggung meninggal dalam masa asuransi, maka kepada tertanggung akan dibayarkan sebesar uang pertanggungan. Begitu sebaliknya, yaitu dengan perhitungan dibawah ini.

$$
\begin{aligned}
P_{19: \overline{4} \mid} & =1,500,000 \frac{\left(M_{19}-M_{19+4}+D_{19+4}\right)}{N_{19}-N_{19+4}} \\
& =1.500 .000 \frac{227,3584-155,9608+6390,209}{91450,0666} \\
& =R p 279.336
\end{aligned}
$$

- Untuk usia 20 tahun

Jika tertanggung meninggal dalam masa asuransi, maka kepada tertanggung akan dibayarkan sebesar uang pertanggungan. Begitu sebaliknya, yaitu dengan perhitungan sebagai berikut :

$$
\begin{aligned}
P_{20: \overline{4} \mid} & =1.500 .000 \frac{M_{20}-M_{20+4}+D_{20+4}}{N_{20}-N_{20+4}} \\
& =1.500 .000 \frac{206,6155-142,5127+5674,579}{81175,7392-50361,7927} \\
& =R p 279.355
\end{aligned}
$$

\subsection{Analisis Komponen}

Dalam menganalisis komponen-komponen biaya diperlukan nila-nilai dari $A_{x: \bar{n} \mid}, \ddot{a}_{x: \bar{n} \mid}$, $a_{x: \bar{n} \mid}$ yang belum diketahui untuk dimasukkan ke dalam persamaan (11)

Setelah nilai dari $A_{x: \bar{n} \mid}, \ddot{a}_{x: \bar{n} \mid}, a_{x: \bar{n} \mid}$ sudah diketahui maka selanjutnya akan menganalisis komponen-komponen biaya tersebut dengan menggunakan rumus

$$
P_{x: \bar{n} \mid}=\frac{A_{x: \bar{n} \mid}+\alpha_{1}+\gamma \ddot{a}_{x: \bar{n} \mid}}{\left((1-\beta) a_{x: \bar{n} \mid}\right)-\alpha_{2} n}
$$

- Analisis komponen biaya pada umur 17 tahun dijabarkan sebagai berikut :

$$
\begin{aligned}
& P_{x: \bar{n} \mid}=\frac{A_{x: \bar{n} \mid}+\alpha_{1}+\gamma \ddot{a}_{x: \bar{n} \mid}}{\left((1-\beta) a_{x: \bar{n} \mid}\right)-\alpha_{2} n} \\
& P_{x: \bar{n} \mid}^{\rightarrow}=\frac{0,6287+\alpha_{1}+\gamma 3,3782}{((1-\beta) 3,0006)-\alpha_{2} 4} \\
& P_{x: \overline{n \mid}}^{\rightarrow}\left[(1-\beta) 3,0006-\alpha_{2} 4\right]=0,6287+\alpha_{1}+\gamma 3,3782 \\
& P_{x: \bar{n} \mid}^{\rightarrow}\left[(1-\beta) 3,0006-\alpha_{2} 4\right]-0,6287-\alpha_{1}-\gamma 3,3782=0 \\
& P_{x: \bar{n} \mid}^{\overrightarrow{1}}\left[3,0006-\beta 3,0006-\alpha_{2} 4\right]-0,6287-\alpha_{1}-\gamma 3,3782=0 \\
& P_{x: \bar{n} \mid}^{\rightarrow} 3,0006-\beta 3,0006 P_{x: \bar{n} \mid}^{\rightarrow}-\alpha_{2} 4 P_{x: \bar{n} \mid}^{\rightarrow}-0,6287-\alpha_{1}-\gamma 3,3782=0 \\
& -\beta 3,0006-\alpha_{2} 4 P_{x: \bar{n} \mid}^{\overrightarrow{ }}-\alpha_{1}-\gamma 3,3782+P_{x: \bar{n} \mid} 3,0006-0,6287=0 \\
& -\left(\beta 3,0006 P_{x: \bar{n} \mid}^{\overrightarrow{1}}+\alpha_{2} 4 P_{x: \bar{n} \mid}^{\overrightarrow{1}}+\alpha_{1}+\gamma 3,3782-P_{x: \bar{n} \mid}^{\overrightarrow{1}} 3,0006+0,6287\right)=0 \\
& \gamma 3,3782+\alpha_{1}+\alpha_{2} 4 P_{x: \bar{n} \mid}^{\overrightarrow{ }}+\beta 3,0006 P_{x: \bar{n} \mid}^{\vec{A}}-P_{x: \bar{n} \mid}^{\overrightarrow{3}} 3,0006+0,6287=0 \\
& \gamma 3,3782+\alpha_{1}+\alpha_{2} 4 P_{x: \bar{n} \mid}^{\overrightarrow{1}}+\beta 3,0006 P_{x: \bar{n} \mid}^{\overrightarrow{ }}-3,0006 P_{x: \bar{n} \mid}^{\overrightarrow{ }}+0,6287=0
\end{aligned}
$$


$\alpha_{1}+\gamma 3,3782+\beta 3,0006(279.162)+\alpha_{2} 4(279.162)=3,0006(279.162)-0,6287$

$\alpha_{1}+\gamma 3,3782+\beta 837.653,4972+\alpha_{2} 1.116 .648=837.652,8685$

- Analisis komponen biaya pada umur 18 tahun dijabarkan sebagai berikut :

$P_{x: \overline{n \mid}}^{\overrightarrow{ }}=\frac{A_{x: \bar{n} \mid}+\alpha_{1}+\gamma \ddot{a}_{x: \bar{n} \mid}}{\left((1-\beta) a_{x: \bar{n} \mid}\right)-\alpha_{2} n}$

$P_{x: \bar{n} \mid}^{\rightarrow}=\frac{0,6288+\alpha_{1}+\gamma 3,3775}{((1-\beta) 2,9996)-\alpha_{2} 4}$

$P_{x: \overline{n \mid}}^{\rightarrow}\left[(1-\beta) 2,9996-\alpha_{2} 4\right]=0,6288+\alpha_{1}+\gamma 3,3775$

$P_{x: \bar{n} \mid}^{\rightarrow}\left[(1-\beta) 2,9996-\alpha_{2} 4\right]-0,6288-\alpha_{1}-\gamma 3,3775=0$

$\overrightarrow{P_{x: \bar{n} \mid}}\left[2,9996-\beta 2,9996-\alpha_{2} 4\right]-0,6288-\alpha_{1}-\gamma 3,3775=0$

$\overrightarrow{P_{x: \bar{n} \mid}} 2,9996-\beta 2,9996 P_{x: \bar{n} \mid}^{\vec{n}}-\alpha_{2} 4 \overrightarrow{P_{x: \bar{n} \mid}}-0,6288-\alpha_{1}-\gamma 3,3775=0$

$-\beta 2,9996 P_{x: \bar{n} \mid}^{\vec{A}}-\alpha_{2} 4 P_{x: \bar{n} \mid}^{\vec{n}}-\alpha_{1}-\gamma 3,3775+P_{x: \bar{n} \mid}^{\overrightarrow{2}} 2,9996-0,6288=0$

$-\left(\beta 2,9996+\alpha_{2} 4 P_{x: \bar{n} \mid}^{\rightarrow}+\alpha_{1}+\gamma 3,3775-P_{x: \bar{n} \mid}^{\overrightarrow{2}} 2,9996+0,6288\right)=0$

$\gamma 3,3775+\alpha_{1}+\alpha_{2} 4 P_{x: \bar{n} \mid}^{\overrightarrow{1}}+\beta 2,9996 P_{x: \bar{n} \mid}^{\overrightarrow{1}}-P_{x: \bar{n} \mid} 2,9996+0,6288=0$

$\gamma 3,3775+\alpha_{1}+\alpha_{2} 4 P_{x: \bar{n} \mid}^{\rightarrow \vec{n}}+\beta 2,9996 P_{x: \bar{n} \mid}^{\vec{a}}-2,9996 P_{x: \bar{n} \mid}^{\rightarrow}+0,6288=0$

$\alpha_{1}+\gamma 3,3775+\beta 2,9996(279.279)+\alpha_{2} 4(279.279)=2,9996(279.279)-0,6288$

$\alpha_{1}+\gamma 3,3775+\beta 837.725,2884+\alpha_{2} 1.117 .116=837.724,6596$

- $\quad$ Analisis komponen biaya pada umur 19 tahun dijabarkan sebagai berikut :

$$
\begin{aligned}
& P_{x: \bar{n} \mid}^{\overrightarrow{ }}=\frac{A_{x: \bar{n} \mid}+\alpha_{1}+\gamma \ddot{a}_{x: \bar{n} \mid}}{\left((1-\beta) a_{x: \bar{n} \mid}\right)-\alpha_{2} n} \\
& P_{x: \bar{n} \mid}^{\rightarrow}=\frac{0,6289+\alpha_{1}+\gamma 3,3772}{((1-\beta) 2,9991)-\alpha_{2} 4} \\
& P_{x: \overline{n \mid}}^{\rightarrow}\left[(1-\beta) 2,9991-\alpha_{2} 4\right]=0,6289+\alpha_{1}+\gamma 3,3772 \\
& P_{x: \bar{n} \mid}^{\rightarrow}\left[(1-\beta) 2,9991-\alpha_{2} 4\right]-0.6289-\alpha_{1}-\gamma 3,3772=0 \\
& \overrightarrow{P_{x: \bar{n} \mid}}\left[2,9991-\beta 2,9991-\alpha_{2} 4\right]-0,6289-\alpha_{1}-\gamma 3,3772=0 \\
& P_{x: \bar{n} \mid}^{\rightarrow} 2,9991-\beta 2,9991-\alpha_{2} 4 P_{x: \bar{n} \mid}^{\rightarrow}-0,6289-\alpha_{1}-\gamma 3,3772=0 \\
& -\beta 2,9991 P_{x: \bar{n} \mid}^{\overrightarrow{ }}-\alpha_{2} 4 P_{x: \bar{n} \mid}^{\overrightarrow{1}}-\alpha_{1}-\gamma 3,3772+P_{x: \bar{n} \mid}^{\overrightarrow{1}} 2,9991-0,6289=0 \\
& -\left(\beta 2,9991 P_{x: \bar{n} \mid}^{\overrightarrow{1}}+\alpha_{2} 4 P_{x: \bar{n} \mid}^{\overrightarrow{1}}+\alpha_{1}+\gamma 3,3772-P_{x: \bar{n} \mid}^{\overrightarrow{2}} 2,9991+0,6289\right)=0 \\
& \gamma 3,3772+\alpha_{1}+\alpha_{2} 4 P_{x: \bar{n} \mid}^{\overrightarrow{ }}+\beta 2,9991 P_{x: \bar{n} \mid}^{\rightarrow}-P_{x: \bar{n} \mid}^{\overrightarrow{1}, 9991+0,6289=0} \\
& \gamma 3,3772+\alpha_{1}+\alpha_{2} 4 P_{x: \bar{n} \mid}^{\rightarrow}+\beta 2,9991 P_{x: \bar{n} \mid}^{\vec{a}}-2,9991 P_{x: \bar{n} \mid}^{\rightarrow}+0,6289=0 \\
& \alpha_{1}+\gamma 3,3772+\beta 2,9991(279.336)+\alpha_{2} 4(279.336)=2,9991(279.336)-0,6289 \\
& \alpha_{1}+\gamma 3,3772+\beta 837.756,5976+\alpha_{2} 1.117 .344=837.755,9687
\end{aligned}
$$

Analisis komponen biaya pada umur 20 tahun dijabarkan sebagai berikut :

$$
\begin{aligned}
& P_{x: \bar{n} \mid}=\frac{A_{x: \bar{n} \mid}+\alpha_{1}+\gamma \ddot{a}_{x: \bar{n} \mid}}{\left((1-\beta) a_{x: \bar{n} \mid}\right)-\alpha_{2} n} \\
& P_{x: \bar{n} \mid}^{\rightarrow}=\frac{0,6289+\alpha_{1}+\gamma 3,3770}{((1-\beta) 2.9989)-\alpha_{2} 4} \\
& P_{x: \overline{n \mid}}^{\rightarrow}\left[(1-\beta) 2,9989-\alpha_{2} 4\right]=0,6289+\alpha_{1}+\gamma 3,3770 \\
& P_{x: \bar{n} \mid}^{\rightarrow}\left[(1-\beta) 2,9989-\alpha_{2} 4\right]-0,6289-\alpha_{1}-\gamma 3,3770=0 \\
& P_{x: \bar{n} \mid}^{\vec{n}}\left[2,9989-\beta 2,9989-\alpha_{2} 4\right]-0,6289-\alpha_{1}-\gamma 3,3770=0 \\
& P_{x: \bar{n} \mid}^{\vec{a}} 2,9989-\beta 2,9989 P_{x: \bar{n} \mid}^{\overrightarrow{ }}-\alpha_{2} 4 P_{x: \bar{n} \mid}^{\overrightarrow{1}}-0,6289-\alpha_{1}-\gamma 3,3770=0 \\
& -\beta 2,9989 P_{x: \bar{n} \mid}^{\overrightarrow{ }}-\alpha_{2} 4 P_{x: \bar{n} \mid}^{\vec{n}}-\alpha_{1}-\gamma 3,3770+P_{x: \overline{n \mid}}^{\overrightarrow{1}} 2,9989-0,6289=0 \\
& -\left(\beta 2,9989 P_{x: \bar{n} \mid}^{\vec{m}}+\alpha_{2} 4 P_{x: \bar{n} \mid}^{\vec{m}}+\alpha_{1}+\gamma 3,3770-P_{x: \bar{n} \mid}^{\vec{m}} 2,9989+0,6289\right)=0
\end{aligned}
$$




$$
\begin{aligned}
& \gamma 3,3770+\alpha_{1}+\alpha_{2} 4 P_{x: \bar{n} \mid}^{\rightarrow}+\beta 2,9989 P_{x: \bar{n} \mid}^{\rightarrow}-P_{x: \bar{n} \mid}^{\overrightarrow{2}} 2,9989+0,6289=0 \\
& \gamma 3,3770+\alpha_{1}+\alpha_{2} 4 P_{x: \bar{n}}^{\vec{x}}+\beta 2,9989 P_{x: \bar{n} \mid}^{\rightarrow}-2,9989 P_{x: \bar{n} \mid}^{\rightarrow}+0,6289=0 \\
& \alpha_{1}+\gamma 3,3770+\beta 2,9989(279.355)+\alpha_{2} 4(279.355)=2,9989(279.355)-0,6289 \\
& \alpha_{1}+\gamma 3,3770+\beta 837.757,7095+\alpha_{2} 1.117 .420=837.757,0806
\end{aligned}
$$

Dari hasil diatas maka di dapat persamaan sebagai berikut :

$$
\begin{gathered}
\alpha_{1}+3,3782 \gamma+837.653,4972 \beta+1.116 .648 \alpha_{2}=837.625,8685 \\
\alpha_{1}+3,3775 \gamma+837.725,884 \beta+1.117 .116 \alpha_{2}=837.724,6596 \\
\alpha_{1}+3,3772 \gamma+837.756,5976 \beta+1.117 .344 \alpha_{2}=837.755,9687 \\
\alpha_{1}+3,3770 \gamma+837.757,7095 \beta+1.117 .420 \alpha_{2}=837.757,0806
\end{gathered}
$$

Dari persamaan diatas dapat dituliskan matriks sebagai berikut :

$$
A X=B
$$

dengan

$$
A=\left[\begin{array}{cccc}
1 & 3,3782 & 837.653,4972 & 1.116 .648 \\
1 & 3,3775 & 837.725,884 & 1.117 .116 \\
1 & 3,3772 & 837.756,5976 & 1.117 .344 \\
1 & 3,3770 & 837.757,7095 & 1.117 .420
\end{array}\right] X=\left[\begin{array}{c}
\alpha_{1} \\
\gamma \\
\beta \\
\alpha_{2}
\end{array}\right] B=\left[\begin{array}{l}
837.625,8685 \\
837.724,6596 \\
837.755,9687 \\
837.757,0806
\end{array}\right]
$$

Maka diperoleh :

atau

$$
\left[\begin{array}{c}
\alpha_{1} \\
\gamma \\
\beta \\
\alpha_{2}
\end{array}\right]=\left[\begin{array}{cccc}
1 & 3,3782 & 837.653,4972 & 1.116 .648 \\
1 & 3,3775 & 837.725,884 & 1.117 .116 \\
1 & 3,3772 & 837.756,5976 & 1.117 .344 \\
1 & 3,3770 & 837.757,7095 & 1.117 .420
\end{array}\right]^{-1}\left[\begin{array}{c}
837.625,8685 \\
837.724,6596 \\
837.755,9687 \\
837.757,0806
\end{array}\right]
$$

$$
\left[\begin{array}{c}
\alpha_{1} \\
\gamma \\
\beta \\
\alpha_{2}
\end{array}\right]=\left[\begin{array}{cccc}
14380.2969 & -18802.58 & -56160.3 & 60583.62 \\
5359.35091 & -18189.08 & 18316.59 & -5486.86 \\
-0.0587264 & 0.1627854 & -0.05461 & -0.04945 \\
0.01496274 & -0.050248 & 0.035843 & -0.00056
\end{array}\right]\left[\begin{array}{l}
837.625,8685 \\
837.724,6596 \\
837.755,9687 \\
837.757,0806
\end{array}\right]
$$

maka didapat hasil biaya komponen-komponen sebagai berikut :

$$
\left[\begin{array}{c}
\alpha_{1} \\
\gamma \\
\beta \\
\alpha_{2}
\end{array}\right]=\left[\begin{array}{l}
11199.1821 \\
10832.6678 \\
0.90304953 \\
0.02992543
\end{array}\right]
$$

Kemudian dari persamaan ini akan dicari solusi dari $\alpha_{1} \alpha_{2} \beta$ dan $\gamma$ Dengan menggunakan metode invers matriks, maka diperoleh solusi dari matriks $A$ masing-masing untuk biaya penutupan baru pada awal tahun $\alpha_{1}=11.199,1821$, biaya penutupan baru pada akhir tahun $\alpha_{2}=0,0299$, biaya pengumpulan premi $\beta=0,9030$, dan biaya penutupan baru $\gamma=10.832,6678$ dengan besaran komponen biaya untuk uang pertanggungan sebesar Rp 1.500.000.

\section{Kesimpulan}

1. Besarnya komponen-komponen biaya yang di peroleh dari proses analisis dengan menggunakan metode matriks invers, untuk uang pertanggungan sebesar Rp. 1.500.000 maka, untuk biaya penutupan baru sebesar Rp. 11.199,1821 dan Rp. 0,0299, biaya pengumpulan premi sebesar Rp. 0,9030 dan biaya untuk pemeliharaan sebesar Rp. 10.832,6678.

2. Premi netto tahunan asuransi jiwa dwiguna pada perusahaan asuransi Bumi Putra yang harus dibayarkan oleh tertanggung dengan usia 17 tahun adalah Rp. 279.162, untuk usia 18 tahun sebesar Rp. 279.279 , untuk usia 19 tahu sebesar Rp. 279.336, untuk usia 20 tahun sebesar Rp. 279. 355. 


\section{Daftar Pustaka}

[1] Pungky, J.A.S. 2010. Asuransi Jiwa. PT. Prudential Life Surakarta

[2] Suprabawa, P.J.A.2010. Asuransi Jiwa. PT. Prudential Life.Surakarta.

[3] Trisnawati, D.N, I. N. Widana, dan K. Jayanegara. 2014. Analisis Komponen Biaya Asuransi Jiwa Dwiguna(endowment). Jurnal Matematika. 4 (1): 12-21.

[4] Sari, E.K, dan A. Simangunsong. 2007. Hukum dalam Ekonomi. Grasindo. Jakarta.

[5] Senduk, S. 1999. Mempersiapkan dana Pendidikan Anak. Gramedia. Jakarta

[6] Ridwansyah, I., N. Nurani, R. G. Aida, E. R. Suhardjadinata, R. Laksono, dan M. Rachmawati. 2004. Analisis Perhitungan Premi Asuransi Jiwa Dwiguna dengan Menggunakan Metoda Komutasi. Jurnal Bisnis, Manajemen \& Ekonomi. 5 (4): 187-198

[7] Futami, T. 1993.. Matematika Asuransi Jiwa Bagian I. Incorperated Foundation Oriental Life Insurance Cultural Development Center. Tokyo, Japan.

[8] Bowers, N.L, Gerber, Hickman, Jones, and Nesbit. 1997. Actuarial Mathematics. IPC Publishing Co. St. Joseph, Mich. America.

[9] Anton, H., and C. Rorres. 2014. Elementary Linier Algebra. Wiley. Canada.

[10] Ruminta. 2014. Matriks Persamaan Linier dan Pemrograman Linier. Rekayasa Sains. Bandung.

[11] Manurung, T., dan M. Mananohas. 2016. Taksiran Distribusi Aggregate Lost Asuransi Mobil Menggunakan Fast Fourier Transform (FFT) Dalam Menentukan Premi Murni. Jurnal de Cartesian 5 (2):63 - 71.

[12] Ibrahim, M. I., J. Titaley, dan T. K. Manurung. 2017. Analisis Keakuratan Capital Asset Pricing (CAPM) dan Arbitrage Pricing Theory (APT) Dalam Memprediksi Expected Saham Dalam LQ 45. Jurnal de Cartesian. 6 (1):30 - 44. 